\title{
Extracts from Amazonian plants have inhibitory activity against tyrosinase: an in vitro evaluation
}

\author{
Daclé Juliani Macrini'*, Ivana Barbosa Suffredini², Antonio Drauzio Varella ${ }^{2}$, \\ Riad Naim Younes ${ }^{2}$, Mitsuko Taba Ohara ${ }^{3}$
}

${ }^{1}$ Health Sciences Institute, University Paulista, ${ }^{2}$ Laboratory of Extraction, University Paulista, ${ }^{3}$ Faculty of Pharmaceutical Sciences, University of São Paulo.

\begin{abstract}
Dermatological disorders related to pigmentation result in tenuous hyper or hypopigmentation Cosmetic and pharmaceutical products containing depigmenting substances are used in the treatment of patients who have high pigmentation disorders, such as melasma or chloasma, post-inflammatory hyperpigmentation, senile lentigo and ephelides. Skin lightening agents are not yet totally effective or safe and therefore intensive research for the discovery of new agents is continuous. Enzyme inhibitors involved in melanogenesis, such as tyrosinase, have been discovered in Asian countries, including those isolated from plant extracts. The Brazilian flora has the highest species diversity in the world, and the chemical, pharmacological and cosmetic potential for the discovery of new skin whitening agents is in proportion with this biodiversity. For these reasons, 25 aqueous and 24 organic extracts obtained from 19 plants native to the Amazon rain forest and to the Atlantic forest, belonging to 11 different families, were evaluated as tyrosinase inhibitors. Nine out of 49 extracts showed inhibitory activity in the screening process. The $50 \%$ inhibitory activity $\left(\mathrm{IA}_{50}\right)$ was calculated, revealing that the most active extracts were the organic extracts from the leaves and stem of Ruprechtia sp. $\left(\mathrm{IA}_{50} 33.76 \mathrm{mg} \cdot \mathrm{mL}^{-1}\right)$ and the organic extract from the aerial organs of Rapanea parviflora $\left(\mathrm{IA}_{50} 64.19 \mathrm{mg} \cdot \mathrm{mL}^{-1}\right)$.
\end{abstract}

Uniterms: Tyrosinase. Melanin. Plant extract/in vitro evaluation. Skin lightening agents. Amazonian plants/evaluation/dermatological use.

Problemas dermatológicos relacionados com a pigmentação resultam em hiperpigmentações ou hipopigmentação cutâneas. Produtos cosméticos e farmacêuticos com atividade despigmentante são utilizados para o tratamento de pacientes que apresentam distúrbios de hiperpigmentação, tais como melasma ou cloasma, hiperpigmentação pós-inflamatória, lentigem senil e efélides. Os despigmentantes atualmente utilizados não são totalmente eficazes ou seguros, razão pela qual há intensa pesquisa, principalmente em países asiáticos, com a finalidade de se obter novos agentes com esta ação, em especial inibidores de enzimas envolvidas na melanogênese, como a tirosinase. Considerando-se que algumas substâncias obtidas de plantas apresentam essa atividade, a flora brasileira constitui-se uma fonte potencial de obtenção de novos despigmentantes. Por essa razão, 25 extratos aquosos e 24 orgânicos obtidos de 19 plantas da Floresta Amazônica e Mata Atlântica, provenientes de 11 diferentes famílias, foram avaliados quanto à atividade de inibição da tirosinase. Do total de 49 extratos testados, 9 mostraram atividade. Os valores de concentração da atividade inibitória 50\% (AI 50\%), foram calculados e o mais ativo foi o extrato orgânico das folhas e caule de Ruprechtia sp. $\left(\mathrm{AI}_{50} 33,76 \mathrm{mg} \cdot \mathrm{mL}^{-1}\right)$ seguido do extrato orgânico dos órgãos aéreos de Rapanea parviflora $\left(\mathrm{AI}_{50} 64,19 \mathrm{mg} \cdot \mathrm{mL}^{-1}\right)$.

Unitermos: Tirosinase. Melanina. Extrato de plantas/avaliação in vitro. Despigmentantes. Plantas amazônicas/avaliação/uso dermatológico.

\section{INTRODUCTION}

For centuries, humans have tried to artificially

*Correspondence: D.J. Macrini. Instituto de Ciências da Saúde, Universidade Paulista - UNIP, Av. Dr. Bacelar, 1212, 04026-002 - São Paulo - SP, Brasil, Tel: 5511 5586-4074; FAX: 5511 276-0500.E-mail: daclejm@usp.br. modify the color of their skin, both by using whitening or darkening products. Such attitudes were related to philosophy, beliefs, religion and mainly to vanity (Shevlin, 1974). Over-exposure of the skin to ultraviolet light is related to human ostentation, but it can also be related to pigmenting problems or even to skin cancer (Podahaisky 
et al., 2002). As the world population ages it becomes even more important to treat pigment disorders (Benech, 2002). Severe anomalies may also hamper an individual in social relationships (Grimes, 1999).

Both hyper and hypopigmentation are treated with cosmetic or pharmaceutical products containing depigmenting substances, which are synthetic or of natural origin. Pigmentation disorders can also be treated with mechanical peeling allied to chemical substances or treatments with laser rays (Grimes, 1999).

The skin produces a complex mixture of enzymes for protection from the constant exposition to environmental oxidative stress (Podahaisky et al., 2002), but in some situations this is insufficient to prevent disorders from appearing. However, the fact that drugs can be absorbed by the skin (Thorsteinsson et al., 1999) aids in the development of cosmetic preparations to treat skin pigmentation or depigmentation, particularly drugs whose active substance is a natural product.

One of the most effective depigmenting substances is hydroquinone, which inhibits the synthesis of melanin. Enzyme inhibition is one of the mechanisms involved in melanogenesis (Lee, Choi, 1998).

Many screening studies are reported in the literature, with emphasis on those products made with tyrosinase inhibitors from African plants (Baurin et al., 2002; Kubo, Hori, 1999b, Momtaz et al., 2008), Bolivia (Kubo et al., 1995), China (Iida et al., 1995; Masamoto et al., 1980; Miao et al., 1997), Japan (No et al., 1999), Bangladesh (Khanom et al., 2000) and others. Positive results in relation to activity were obtained and some authors continued this work by isolating active substances.

Considering that current therapies have shown less than satisfactory results in the treatment of various dermatological disorders such as melasma, post-inflammatory or senile lentigo and ephelides, and that the side effects of the therapy include high cytotoxicity and mutagenicity, poor skin penetration and low stability of formulations (Grimes, 1999; Nerva et al., 2003), new drugs with enzyme inhibitory activity are needed( $\mathrm{Su}, 1999)$.

Satisfactory results obtained from screening studies previously conducted by other groups, reporting the identification of inhibitory activity of melanogenesis by plant extracts, allied with the fact that Brazilian biodiversity corresponds to $20 \%$ of the world's biodiversity (Suffredini et al., 2004) justify the current project of screening Brazilian plant extracts such as tyrosinase inhibitors in vitro, so that agents may be found and eventually used in cosmetic and pharmaceutical products.

\section{MATERIAL AND METHODS}

\section{Plant extracts}

The plant material listed in Table I was collected from igapó, terra firme and Atlantic forests, according to a chemosystematic approach. Vouchers were deposited in the Herbarium UNIP, where they were identified. After collection, the material was ground up and $24 \mathrm{~h}$-macerated with a mixture of dichloromethane and methanol (1:1), followed by 24h-maceration with MilliQ water. The organic extracts were evaporated under reduced pressure (Büchi) and the aqueous extracts were lyophilized (Virtis). All the extracts were stored in a freezer $\left(-27^{\circ} \mathrm{C}\right.$, Revco) until use (Younes et al., 2000).

\section{Tyrosinase enzymatic reaction assay}

The assay was realized with modifications (Khanom, 2000; Kobayashi et al., 1995), such that $10 \mathrm{~mL}$ of the solution made with $120 \mathrm{U} \cdot \mathrm{mL}^{-1}$ (1 st screening) or 480 U.mL $\mathrm{mL}^{-1}$ (2nd screening) of tyrosinase obtained from mushrooms (Sigma) were added to 96-well microplates, as were $70 \mathrm{~mL}$ of $\mathrm{pH} 6.8$ buffer solution and $60 \mathrm{~mL}$ of the plant extract solutions (water or DMSO 50\% in water, were used as vehicles). A negative control was used, as was a positive control made with a solution of kojic acid. To this mixture, $70 \mu \mathrm{L}$ of L-tyrosine (Sigma) were added, completing the final volume up to $210 \mu \mathrm{L}$. The absorbance was taken at $490 \mathrm{~nm}$ in a microplate spectrophotometer reader (Biotek) in the beginning of the reaction, as the time zero reading. Microplates were incubated at $(30 \pm 1)^{\circ} \mathrm{C}$ for 120 minutes in the first screening, and for 60 minutes in the second screening. Optical densities were registered on a computer coupled to the spectrophotometer reader. Inhibitory activity of $50 \%$ was obtained according to the formula

$\operatorname{IA}(\%)=\left[\left(\left(C-\mathrm{T}_{0}\right)-\left(\mathrm{S}-\mathrm{T}_{0}\right)\right) /\left(\mathrm{C}-\mathrm{T}_{0}\right)\right] \times 100$

where IA = inhibitory activity, $\mathrm{C}=$ control absorbance at $490 \mathrm{~nm}, \mathrm{~S}=$ test absorbance at $490 \mathrm{~nm}$ and $\mathrm{T}_{0}=$ time zero, and each parameter was a mean of 8 measures.

The percentage of inhibitory activity of tyrosinase obtained from the extracts was compared to that obtained from the kojic acid.

\section{Tyrosinase inhibitory activity by plant extracts}

The first screening was performed as previously described, using tyrosinase at $120 \mathrm{U} \cdot \mathrm{mL}^{-1}$. The final 
concentration in the assay was $80 \mu \mathrm{g} / \mathrm{mL}\left(\mu \mathrm{g} \cdot \mathrm{ml}^{-1}\right)$ for the extracts, and $5 \mu \mathrm{g} . \mathrm{mL}^{-1}$ for kojic acid, used as a positive control. Readings were taken 120 minutes after the addition of the extract or kojic acid. The active extracts were submitted to a second screening, whose enzyme concentration was 480 U.mL ${ }^{-1}$.

\section{Determination of the inhibitory activity at $50 \%$, of kojic acid using tyrosinase at concentrations of 120 U.mL $\mathrm{mb}^{-1}$ and 480 U.mL}

The test was performed as first described. Tyrosinase was diluted to $120 \mathrm{U} \cdot \mathrm{mL}^{-1}$ and $480 \mathrm{U} \cdot \mathrm{mL}^{-1}$, in the first and second screening, respectively. Kojic acid concentrations used in the test were 5.0, 4.0, 3.0, 2.5, $1.25,0.625$ and $0.3125 \mu \mathrm{g} . \mathrm{mL}^{-1}$ in the first screening, and $10.0,5.0,2.5,1.25$ and $0.625 \mu \mathrm{g} . \mathrm{mL}^{-1}$ in the second screening.

\section{Determination of the inhibitory activity at $50 \%$, of the active extracts}

The test was executed as first described, substituting the kojic acid by plant extracts, whose concentrations were 80.0, 40.0, 20.0 and $10.0 \mu \mathrm{g} . \mathrm{mL}^{-1}$.

TABLE I - List of Amazonian Rain Forest plant extracts tested against tyrosinase

\begin{tabular}{|c|c|c|c|c|}
\hline Extract* & Species & Family & Plant organ & Collection number \\
\hline $\begin{array}{l}01 / \mathrm{O} \\
02 / \mathrm{A}\end{array}$ & Calophyllum brasiliense Cambess & Clusiaceae & Stem & PS187 \\
\hline $\begin{array}{l}03 / \mathrm{O} \\
04 / \mathrm{A}\end{array}$ & Ruprechtia sp. & Polygonaceae & Leaves and Stem & PS387 \\
\hline $\begin{array}{l}05 / \mathrm{O} \\
06 / \mathrm{A}\end{array}$ & Mabea nitida Spruce ex Benth & Euphorbiaceae & Leaves and Stem & PS81 \\
\hline $\begin{array}{l}07 / \mathrm{O} \\
08 / \mathrm{A}\end{array}$ & Piranhea trifoliata Baill. & Euphorbiaceae & Leaves & PS88 \\
\hline $09 / \mathrm{A}$ & Aparisthmium cordatum (A. Juss) Baill. & Euphorbiaceae & Aerial organs & PS393 \\
\hline $\begin{array}{l}10 / \mathrm{O} \\
11 / \mathrm{A} \\
\end{array}$ & Piranhea trifoliata Baill. & Euphorbiaceae & Fruits & PS88 \\
\hline $\begin{array}{l}12 / \mathrm{O} \\
13 / \mathrm{A}\end{array}$ & Calophyllum brasiliense Cambess & Clusiaceae & Fruits & PS187 \\
\hline $\begin{array}{l}14 / \mathrm{O} \\
15 / \mathrm{A} \\
\end{array}$ & Mabea nitida Spruce ex Benth. & Euphorbiaceae & Fruits & PS81 \\
\hline $\begin{array}{l}16 / \mathrm{O} \\
17 / \mathrm{A}\end{array}$ & Malouetia tamaquarina (Aubl.) A. DC. & Apocynaceae & Aerial organs & IBS10 \\
\hline $\begin{array}{l}18 / \mathrm{O} \\
19 / \mathrm{A}\end{array}$ & Calophyllum brasiliense Cambess & Clusiaceae & Leaves & PS187 \\
\hline $\begin{array}{l}20 / \mathrm{O} \\
21 / \mathrm{A}\end{array}$ & Duguetia uniflora (DC.) Mart. & Annonaceae & Stem bark & PS357 \\
\hline $\begin{array}{l}22 / \mathrm{O} \\
23 / \mathrm{A}\end{array}$ & Guatteria riparia R. E. Fr. & Annonaceae & Stem & PS115 \\
\hline $\begin{array}{l}24 / \mathrm{O} \\
25 / \mathrm{A}\end{array}$ & Crudia amazonica Spruce ex Benth. & $\begin{array}{c}\text { Leguminosae } \\
\text { Caesalpinioidae }\end{array}$ & Stem & PS90 \\
\hline $26 / \mathrm{A}$ & Guatteria riparia R. E. Fr. & Annonaceae & Leaves & PS115 \\
\hline $\begin{array}{l}27 / \mathrm{O} \\
28 / \mathrm{A}\end{array}$ & Couma utilis (Mart.) Mill. Arg. & Apocynaceae & Leaves & AAO3336 \\
\hline $\begin{array}{l}29 / \mathrm{O} \\
30 / \mathrm{A}\end{array}$ & Macrolobium acaciifolium (Benth.) Benth. & $\begin{array}{c}\text { Leguminosae } \\
\text { Caesalpinoidae }\end{array}$ & Fruits & PS137 \\
\hline
\end{tabular}


TABLE I - List of Amazonian Rain Forest plant extracts tested against tyrosinase (cont.)

\begin{tabular}{|c|c|c|c|c|}
\hline Extract* & Species & Family & Plant organ & Collection number \\
\hline $\begin{array}{l}31 / \mathrm{O} \\
32 / \mathrm{A}\end{array}$ & Hevea microphylla Ule & Euphorbiaceae & Stem & PS196 \\
\hline $\begin{array}{l}33 / \mathrm{O} \\
34 / \mathrm{A}\end{array}$ & Taralea oppositifolia Aubl. & $\begin{array}{c}\text { Leguminosae } \\
\text { Faboidae }\end{array}$ & Leaves & PS108 \\
\hline $\begin{array}{l}35 / \mathrm{O} \\
36 / \mathrm{A}\end{array}$ & Taralea oppositifolia Aubl. & $\begin{array}{c}\text { Leguminosae } \\
\text { Faboidae }\end{array}$ & Fruits & PS108 \\
\hline $\begin{array}{l}37 / \mathrm{O} \\
38 / \mathrm{A}\end{array}$ & Piranhea trifoliata Baill. & Euphorbiaceae & Stem & PS88 \\
\hline $\begin{array}{l}39 / \mathrm{O} \\
40 / \mathrm{A}\end{array}$ & Triplaris surinamensis Cham. & Polygonaceae & Stem & AAO3294 \\
\hline $\begin{array}{l}41 / \mathrm{O} \\
42 / \mathrm{A}\end{array}$ & Davilla rugosa Poir. & Dilleniaceae & Aerial organs & AAO3457 \\
\hline $\begin{array}{l}3 / \mathrm{O} \\
44 / \mathrm{A}\end{array}$ & Passiflora sp. & Passifloraceae & Aerial organs & AAO3421 \\
\hline $\begin{array}{l}45 / \mathrm{O} \\
46 / \mathrm{A} \\
\end{array}$ & Rapanea parviflora Aubl. ** & Myrsinaceae & Aerial organs & AAO3458 \\
\hline $\begin{array}{l}47 / \mathrm{O} \\
48 / \mathrm{A}\end{array}$ & Palicourea grandifolia (A. DC) Mez & Rubiaceae & Aerial organs & AAO3542 \\
\hline $49 / 0$ & Casearia javitensis Kunth & Flacourtiaceae & Aerial organs & AAO4067 \\
\hline
\end{tabular}

\section{RESULTS AND DISCUSSION}

$\mathrm{IA}_{50}$ of the kojic acid obtained from the reaction with tyrosinase at $120 \mathrm{U} \cdot \mathrm{mL}^{-1}$, calculated from the regression line formula generated after 120 minutes of reaction, was $2.99 \mu \mathrm{g} \cdot \mathrm{mL}^{-1}$. The $\mathrm{IA}_{50}$ of the kojic acid, obtained from regression line formula generated from the reaction with tyrosinase at $480 \mathrm{U}_{\mathrm{m}} \mathrm{mL}^{-1}$ after 60 minutes was $6.85 \mu \mathrm{g} . \mathrm{mL}^{-1}$.

Results obtained in the first screening of plant extracts as inhibitors of tyrosinase are shown in Table II (statistical analysis, $\mathrm{T}$ test). The $\mathrm{IA}_{50}$ concentrations are shown in Table III.

Skin clarity is an important characteristic, as hyper and hypopigmentation affect the self-esteem of an individual, but fortunately can be treated, or at least minimized. In the last few years the number of whitening products on the market has increased dramatically, but therapies have not always shown satisfactory results ( $\mathrm{Su}, 1999$; Tengamnuay et al., 2006), This is principally due to the high toxicity of the whitening substances, such as that observed for hydroquinone (Grimes, 1999). The present observations highlight the need for intensive research on new depigmenting substances. The identification of enzyme inhibitors involved in melanogenesis, such as hydroquinone and kojic acid, is especially important.

Given that plants may contain enzyme inhibitory substances, screening methodologies show greater efficacy in the identification of active substances (Lee et al., 1999), and there are calls to search for active compounds from Brazilian plants, the present screening was delineated in order to evaluate plant extracts obtained from plants chemosystematically related to groups whose phenolic compound production is significant (Iida et al., 1995; Kubo, Hori, 1999a; Kubo, 1995; No, 1999). Plants belonging to the families: Annonaceae, Apocynaceae, Clusiaceae, Dilleniaceae, Euphorbiaceae, Flacourtiaceae, Leguminosae, Myrsinaceae, Passifloraceae, Polygonaceae and Rubiaceae were assayed. Some plants of these families have already been evaluated and have been shown to contain phenolic tyrosine inhibitor compounds such as flavonoids and tannins (Iida et al., 1995; Khanom et al., 2000).

The tyrosinase inhibitory effect of 49 aqueous and organic extracts obtained from 19 Brazilian plants belonging to 11 families was evaluated using a spectrophotometric method. Kojic acid was chosen as a positive control because the substance is an effective inhibitor of tyrosinase in vitro (Sandoval, 1999). 
The concentration of tyrosinase used in the first screening was $120 \mathrm{U} \cdot \mathrm{mL}^{-1}$ in order to increase the sensitivity and chances of finding active extracts. As the chemical composition of such extracts is not known, further studies were needed in order to verify the presence of tyrosinase inhibitor substances isolated by bioguided fractionation, and will be discussed below.

Calculations of the extracts' inhibitory activity on melanogenesis were based on the comparison between data obtained from tests with extracts, and from negative controls. The extracts that showed significant inhibitory activity in the 120 minute screening obtained from the first screening (03/0, 07/0, 45/0, 11/A, 50/A, 21/A, 32/A, 34/A and 45/A), and the kojic acid, were submitted to a second screening in order to determine the inhibitory activity $(\mathrm{IA} \%)$ and $\mathrm{IA}_{50}$, using a concentration of tyrosinase of 480 U.mL $\mathrm{mL}^{-1}$.
As shown in Table III, all the extracts except 34/A, demonstrated positive inhibitory activities. Nonetheless, the linearity of the curves obtained to calculate $\mathrm{IA}_{50}$ were not always significant $\left(\mathrm{R}^{2}>0.90\right)$, as was the case with extracts 45/O, 15/A and 21/A.

The relative comparison of test and control $\mathrm{IA}_{50}$ showed that $\mathrm{IA}_{50}$ obtained for kojic acid was $6.85 \mu \mathrm{g}$. $\mathrm{mL}^{-1}$ and that the extract $03 / \mathrm{O}$ (Ruprechtia sp. - stem and leaves - Polygonaceae, $\mathrm{IA}_{50} 33.76 \mu \mathrm{g} \cdot \mathrm{mL}^{-1}$ ) was the most potent enzyme inhibitor. Nonetheless, the dose dependent relationship was not as significant $\left(\mathrm{R}^{2}=0.803\right)$ as that obtained for extract 45/O (Rapanea parviflora - aerial organs - Myrsinaceae, $\left.\mathrm{IA}_{50} 64.19 \mu \mathrm{g} \cdot \mathrm{mL}^{-1}, \mathrm{R}^{2}=0.9935\right)$. Both extracts can be considered potential anti-tyrosinase agents based on the $\mathrm{IA}_{50}$ and $\mathrm{R}^{2}$ values found in the present study and on comparison with the values obtained by Khanom et al. (2000), where kojic acid yielded $\mathrm{IA}_{50}=7.5 \mu \mathrm{g} \cdot \mathrm{mL}^{-1}$,

TABLE II - Tyrosinase reaction in the presence of plant extracts at different concentrations after 60 minutes of exposure

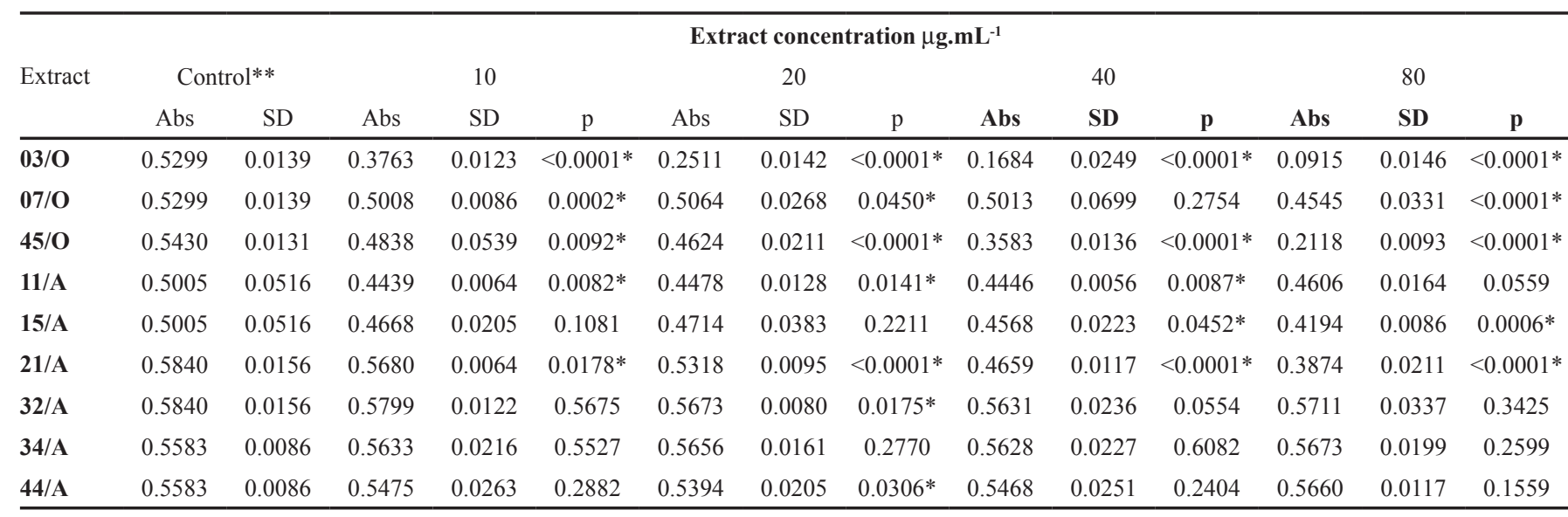

$\mathrm{p}=$ values for test $\mathrm{T} ; *=$ significant; $\mathrm{Abs}=$ mean absorbance $(\mathrm{n}=8) ; \mathrm{SD}=$ Standard deviation; $* *=$ negative control $($ without extract).

TABLE III - Tyrosinase inhibitory activity of plant extracts.

\begin{tabular}{|c|c|c|c|c|c|c|c|}
\hline \multirow{2}{*}{ Extract } & \multicolumn{4}{|c|}{ IA $\% *$} & \multirow{2}{*}{ Equation } & \multirow{2}{*}{$\mathrm{R}^{2}$} & \multirow{2}{*}{$\mathrm{IA}_{50}{ }^{*}$} \\
\hline & 10 & 20 & 40 & 80 & & & \\
\hline $03 / 0$ & 28.99 & 52.61 & 68.22 & 82.73 & $y=0.9282 x+18.664$ & 0.8032 & 33.76 \\
\hline 07/O & 5.50 & 4.40 & 5.40 & 14.23 & $\mathrm{y}=0.1529 \mathrm{x}+1.3198$ & 0.8748 & 318.37 \\
\hline $45 / O$ & 10.91 & 14.85 & 34.02 & 61.00 & $\mathrm{y}=0.7559 \mathrm{x}+1.4798$ & 0.9935 & 64.19 \\
\hline $11 / A$ & 11.31 & 10.54 & 11.16 & 7.97 & $y=0.0446 x+6.8585$ & 0.0872 & nd \\
\hline $15 / A$ & 6.70 & 5.80 & 8.70 & 16.21 & $y=0.1764 x+2.1911$ & 0.9077 & 271.03 \\
\hline 21/A & 2.74 & 8.95 & 20.23 & 33.67 & $y=0.4354 x+0.0568$ & 0.9845 & 114.70 \\
\hline $32 / \mathrm{A}$ & 0.71 & 2.87 & 3.55 & 2.31 & $y=0.0027 x+1.0773$ & 0.3298 & nd \\
\hline 34/A & -0.90 & -1.32 & -0.81 & -1.61 & $y=-0.0144 x-0.4975$ & 0.5511 & nd \\
\hline $44 / A$ & 1.93 & 3.31 & 2.06 & -1.32 & $\mathrm{y}=0.0293 \mathrm{x}+2.0743$ & 0.2537 & nd \\
\hline
\end{tabular}

IA $(\%)=$ percentage of inhibitory activity; $\mathrm{R}^{2}=$ coefficient of linear correlation;

$\mathrm{IA}_{50}=$ inhibitory activity at $50 \%$; $\mathrm{nd}=$ not determined; $*=\mu \mathrm{g} \cdot \mathrm{mL}$ 
and the extract obtained from Glycyrrhyza glabra had $\mathrm{IA}_{50}=21.2 \mu \mathrm{g} \cdot \mathrm{mL}^{-1}$.

\section{CONCLUSIONS}

The extracts obtained from the leaves and stem of Ruprechtia sp. and from the aerial organs of Rapanea parviflora were considered the most active in the present assay. Extracts obtained from the leaves of Piranhea trifoliata, fruits of $P$. trifoliata, fruits of Mabea nitida, stem bark of Duguetia uniflora, stem of Hevea microphylla, leaves of Taralea oppositifolia and the aerial organs of Passiflora sp. were found to exhibit anti-tyrosinase activity. These may be interesting candidates for evaluation in more complex biological system assays such as toxicity in vitro, melanocyte cultures and eventually in human in vivo assays.

\section{ACKNOWLEDGMENTS}

We thank UNIP, especially Dr. Nicolau Tortamano (in memoriam) and Dr. José Jam de Melo; Fapesp (Grant 99/05904-6) and the technicians involved in the process.

\section{REFERENCES}

BAURIN, N.; ARNOULT, E.; SCIOR, T.; DO, Q. T.; BERNARD, P. Preliminary screening of some tropical plants for anti-tyrosinase activity. J. Ethnopharmacol., v.82, p.155-158, 2002.

BENECH, G. Novo ativo clareador extraído de cítricos. Cosmetics \& Toiletries, v.14, p.51-53, 2002.

GRIMES, P. E. The safety and efficacy of salicylic acid chemical peels in darker racial-ethnic groups. Dermatol. Surg., v.25, p.18-22, 1999.

IIDA, K.; HASE, K.; SHIMOMURA, K.; SUDO, S.; KADOTA, S.; NAMBA, T. Potent inhibitors of tyrosinase activity and melanin biosynthesis from Rheum officinale. Planta Med., v.61, p.425-428, 1995.

KHANOM, F.; KAYAHARA, H.; TADASA, K. Tyrosinase inhibitory activity of bangladeshi indigenous medicinal plants. Biosci. Biotechnol. Biochem., v.64, p.1967-1969, 2000 .
KOBAYASHI, Y.; KAYAHARA, H.; TADASA, K.; NAKAMURA, T.; TANAKA, H. Synthesis of amino acid derivates of kojic acid and their tyrosinase inhibitory activity. Biosci. Biotechnol. Biochem., v.59, p.1745-1746, 1995.

KUBO, I.; HORI, I. K. Flavonol from saffron flower: tirosinase inhibitory activity and inhibition mechanism. J. Agric. Food Chem., v.47, p.4121-4125, 1999a.

KUBO, I.; HORI, I. K. 2-Hidroxy-4-methoxybenzaldehyde: a potent tyrosinase inhibitor from African medicinal plants. Planta Med., v.65, p.19-22, 1999b.

KUBO, I.; YOKOKAWA, Y.; HORI, I. K. Tyrosinase inhibitors from Bolivian medicinal plants. J. Nat. Prod., v.58, p.739743, 1995.

LEE, K. K.; CHOI, J. D. Areca catechu L. extract. II. Effects on inflammation and melanogenesis. J. Cosmet. Sci., v.49, p.351-359, 1998.

LEE, K. K.; KIM, J. H.; CHO, J. J.; CHOI, J. D. Inhibitory effect of 150 plant extracts on elastase activity and their anti-inflammatory effects. Int. J. Cosmet. Sci., v.21, p.7182, 1999.

MASAMOTO, Y.; IIDA, S.; KUBO, M. Inhibitory effect of Chinese crude drugs on tyrosinase. Planta Med., v.40, p.361-365, 1980.

MIAO, Z.; KAYAHARA, H.; TADASA, K. Superoxidescavenging and tyrosinase-inhibitory activities of the extracts of some Chinese medicines. Biosci. Biotechnol. Biochem., v.61, p.2106-2108, 1997.

MOMTAZ, S.; MAPUNYA, B. M.; HOUGHTON, P. J.; EDGERLY, C.; HUSSEIN, A.; NAIDOO, S.; LALL, $\mathrm{N}$. Tyrosinase inhibition by extracts and constituents of Sideroxylon inerme L. stem bark, used in South Africa for skin lightening. J. Ethnopharmacol., v.119, n.3, p.507-512, 2008.

NERVA, O.; MUSA, R.; IZRAEL, S.; TAMIR, S. Glabrene and isoliquiritigenin as tyrosinase inhibitors from licorice roots. J. Agric. Food Chem., v.51, p.1201-1207, 2003.

NO, J. K.; SOUNG, D. Y.; KIM, Y. J.; SHIM, K. H.; JUN, Y. S.; RHEE, S. H.; YOKOZAWA, T.; CHUNG, H. Y. Inhibition of tyrosinase by green tea components. Life Sci., v.65, p.241-246, 1999. 
PODHAISKY, H. P.; RIEMSCHNEIDER, S.; WOHLBAB, W. UV light and oxidative damage of the skin. Pharmazie, v.57, p.30-33, 2002.

SANDOVAL, B. Tratamiento del melasma con ácido kójico. Fol. Derm. Per., v.10, p.53-56, 1999.

SHEVLIN, E. J. Skin lighteners and bleach creams. In: BALSAN, M. S.; SAGARIN, E., (Eds.). Cosmetics. New York: John Wiley, 1974. p.223-239.

SU, E. G. Formulando com branqueadores da pele. Cosmetics \& Toiletries, v.11, p.57-63, 1999.

SUFFREDINI, I. B.; SADER, H. S.; GONÇALVES, A. G.; REIS, A. O.; GALES, A. C.; VARELLA, A. D.; YOUNES, R. N. Screening of antibacterial active extracts obtained from plants native to Brazilian Amazon rain forest and Atlantic forest. Braz. J. Med. Biol. Res., v.37, p.379-384, 2004
TENGAMNUAY, P.; PONGRUNGRUANGGWANG, K.; PHEANSRI, I. LIKHITWITAYAWUID, K. Artocarpus eakoocha heartwood extract as a novel cosmetic ingredient: evaluation of the in vitro anti-tyrosinase and in vivo skin whitening activity. Int. J. Cosmet. Sci., v.28, p.269-276, 2006.

THORSTEINSSON, T.; MÁSSON, M.; LOFTSSON, T.; HARALDSSON, G. G.; STEFÁNSSON, E. Diacyl glyceryl ester prodrugs for slow release in the skin: synthesis and in vitro degradation and absorption studies for naproxen derivatives. Pharmazie, v.54, p.831-836, 1999.

YOUNES, R. N.; SUFFREDINI, I. B.; VARELLA, A. D. Extração e rastreamento de novas drogas em plantas brasileiras. Acta Oncol. Bras., v.20, p.15-19, 2000.

Received for publication on $03^{\text {rd }}$ September 2008. Accepted for publication on $09^{\text {th }}$ March 2009. 